\title{
Epidemiological Studies of Target Leaf Spot Disease of White Sarpagandha (Rauvolfia serpentine) Caused by Corynespora cassicola and Rust Disease of Bach (Acorus calamus) Caused by Uromyces acori
}

\author{
Solanki Sarkar and Basudeb Dasgupta* \\ Department of Plant Pathology, Bidhan Chandra Krishi Viswavidyalaya, \\ Mohanpur, Nadia-741252, West Bengal, India \\ *Corresponding author
}

\section{A B S T R A C T}

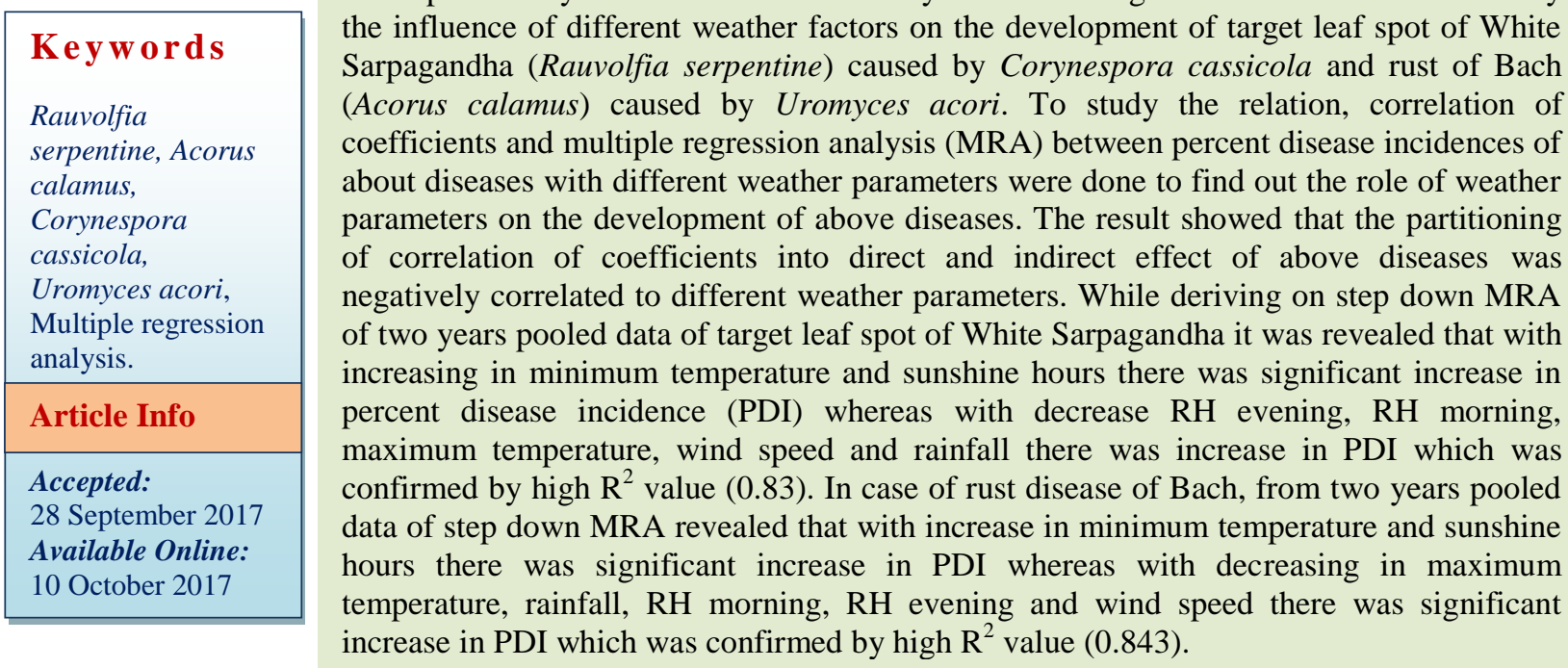

\section{Introduction}

Plants have been used since ancient time mostly to heal and cure human and animal diseases. The wide spread use of medicinal herbs for health care dates back particularly to the early existence of human civilization. More than 30,000 plant species of medicinally important are grown all over the world. Extensive cultivation of these plants has increased the pathological problems. The diseases of these plants and their intensity have increased to a great extent. Several biotic factors like fungi, viruses, bacteria, phytoplasmas, nematodes and abiotic factors like nutrients deficiencies in soil, lack of proper irrigation, etc. are responsible for the maladies of medicinal plants. There are several kinds of disease affecting the plants and each crop plant can be affected by a number of diseases. Disease conditions in the plants are recognized according to the 
symptoms produced by the pathogens. The usual disease symptoms are root rots, cankers, wilts, leaf spots, scabs, blights, anthracnose, rusts, mildews, smuts, mosaics, yellows, root knots, etc. Diseases caused by bacteria, fungi, nematodes, viruses, mycoplasmas are characterized by the presence of these pathogens on the tissues of these plants. The incidence of the diseases of Medicinal plants varies from season to season with the change in climatic condition. Paul (2013) conducted the survey work in the year 2010-2012 at three different locations of West Bengal, India, on a new tip blight and leaf spot disease of Acorus calamus caused by Nigrospora oryzae and the result showed that maximum disease incidence and disease index were recorded during November to February and minimum disease incidence and index of leaf spot or blight by Nigrospora oryzae during May - July, thereafter gradually increased and again reached to the peak during December January.

In this present investigation, attempts have been made to Epidemiological studies of target leaf spot disease of White Sarpagandha (Rauvolfia serpentine) caused by Corynespora cassicola and rust disease of Bach (Acorus calamus) caused by Uromyces acori.

\section{Materials and Methods}

\section{Fixed plot survey}

For fixed plot survey target leaf spot disease of White Sarpagandha caused by Corynespora cassicola and rust disease of Bach caused by Uromyces acori, were selected (Table 1). The survey was conducted at the medicinal plants garden situated at ' $\mathrm{C}$ ' Block farm, BCKV, Kalyani at monthly interval. Ten plants were selected in every plot. For percent disease incidence total no. of leaves/stems infected in a plot were recorded
(Momin, 2009). Percent disease incidence was calculated from the following formulae:

Percent

No. of infected leaves per plant

Disease incidence $=$------------------------ $\times 100$

Total no. of leaves per plant

\section{Weather data collection}

Weather data from January, 2014 to September, 2016 of Kalyani were collected for calculation of correlation with disease incidence and severity from AICRP on Agro Meteorology, BCKV, Kalyani. Seven parameters (Maximum temperature, Minimum temperature, Relative humidity (morning) and Relative humidity (evening), Rainfall, Sunshine hrs. and Wind speed) were recorded.

\section{Multiple regression analysis}

The disease severity in leaves was changing day to day following development of initial foci (onset time). If this variable considered being a dependable variable with weather parameters being the in-dependable variables, then regression equation will describe the relationship. The disease severity is called the dependent (response) variable $\mathrm{Y}$ and is said to regress on the weather parameters are called the independent (determining) variables $\mathrm{X}$. The application of regression analysis to join observations of these variables, permit evaluation of the importance of these independent variables on disease development and means for estimating the change in disease severity which can be expected from a unit change in these variables, thus providing a possible basis for the prediction of the disease severity using such variables as the predictor. Any varying aspect of an epidemic, the disease increase can be considered as a dependent variable and regressed to factors like temperature, relative humidity and other 
parameters. In contrast to regression, correlation measures the degree of association between variables of equal status. There need to be no concept of course and effect. For calculation of correlation of both variables need to be normally distributed whereas for regression this is necessary only for the dependent variables. For study of the multiple effects on dependent variables the multiple regression analysis is done (MRA) as a predictive equation:

$\hat{Y}=b_{0}+b_{1} x_{1}+b_{2} x_{2} \ldots \ldots \ldots \ldots b_{n} x_{n}$

Where,

$\hat{\mathrm{Y}}=$ predicted disease severity

$\mathrm{b}_{0}=$ intercept

$b_{1} b_{2} \ldots \ldots \ldots \ldots b_{n}=$ regression co-efficient

$\mathrm{x}_{1} \mathrm{x}_{2} \ldots \ldots \ldots \ldots \mathrm{X}_{\mathrm{n}}=$ independent variable.

Then the prediction equation and stepwise multiple regression analysis was done by using the following:

$\hat{\mathrm{Y}}=\mathrm{A}+\mathrm{b}_{\mathrm{i}} \mathrm{x}_{\mathrm{i}}+\mathrm{e}$

Where,

$\hat{\mathrm{Y}}=$ predicted severity,

$\mathrm{a}=$ intercept

$b_{i}=$ regression co-efficient for $x_{i}(I=1$ to...n $)$

$\mathrm{x}_{\mathrm{i}}=$ independent variables $(\mathrm{I}=1$ to...... $)$

$\mathrm{e}=$ random error .

\section{Results and Discussion}

Relation of percent disease incidence of leaf spot of medicinal plants with weather parameters

To study the relation, correlation co-efficient between percent diseases incidences of target leaf spot disease of White Sarpagandha caused by Corynespora cassicola and rust disease of Bach caused by Uromyces acori, with different weather parameters was done and the results are presented in Table 3.

The partitioning of correlation of coefficients into direct and indirect effects revealed that the above diseases are negatively correlated with the different weather parameters.

Target leaf spot disease of White sarpagandha

From the first year, it was observed that in White sarpagandha, minimum temperature (0.867 ) and relative humidity at morning (0.722) were negatively significantly correlated with percent disease incidence of target leaf spot disease caused by Corynespora cassicola at $1 \%$ level of significance where maximum temperature ($0.703)$, rainfall $(-0.663)$ and wind speed ($0.700)$ at $5 \%$ level of significance. In second year, maximum (-0.741) and minimum (0.816) temperature were negatively significantly correlated with percent disease incidence at $1 \%$ level of significance where rainfall (-0.579) at 5\% level of significance. Other weather parameters were not significant. In pooled analysis, maximum ($0.722)$ and minimum (-0.831) temperature, rainfall (-0.622) and wind speed (-0.604) were negatively correlated with PDI at $1 \%$ level of significance and relative humidity evening (0.504 ) also showed negative correlation at $5 \%$ level of significance. Relative humidity morning (-0.395) showed negatively not significant relationship (Table 3 ).

\section{Rust disease of Bach}

In Rust disease of Bach, minimum temperature (-0.883), relative humidity at morning (-0.754) and rainfall $(-0.710)$ were negatively correlated with percent disease incidence of rust disease caused by Uromyces acori at $1 \%$ level of significance where maximum temperature (-0.703) and wind 
speed (-0.653) at $5 \%$ level of significance recorded in $1^{\text {st }}$ year observation. In second year, maximum temperature (-0.747) and minimum temperature $(-0.821)$ were negatively correlated with percent disease incidence at $1 \%$ level of significance where only rainfall $(-0.593)$ at $5 \%$ level of significance. In pooled analysis, maximum ($0.722)$ and minimum (-0.845) temperature, relative humidity evening $(-0.527)$, rainfall ($0.653)$ and wind speed (-0.581) were negatively correlated with percent disease incidence at $1 \%$ level of significance where relative humidity morning $(-0.438)$ at $5 \%$ level of significance (Table 3).

\section{Predicted disease severity of Target leaf spot disease of White sarpagandha and Rust disease of Bach}

MRA (Multiple regression ananlysis) was conducted for leaf spot diseases of above medicinal plants to determine the combined effect of weathers factors on disease development. Step down MRA analysis was done to find out the suitable prediction equation for disease severity.

\section{Target leaf spot disease of White} sarpagandha

In white sarpagandha, during first year (July,14 - June,15), the prediction equation for percent disease incidence of target leaf spot disease caused by Corynespora cassicola indicated that RHevening, rainfall and sunshine hours were positively and RHmorning, maxT, minT and wind speed were negatively correlated with percent disease incidence. The coefficient of determination $\left(\mathrm{R}^{2}\right)$ between percent disease incidence and seven groups of independent variables was found to be 0.957 suggesting that $95.7 \%$ change in percent disease incidence was caused by these seven factors. During this period of disease development, weather variables varied from 26.53 $37.68^{\circ} \mathrm{C} \operatorname{maxT}, 11.60-27.32^{\circ} \mathrm{C} \operatorname{minT}, 80.60$ - $96.00 \%$ RHmorning, $37.25-83.50 \%$ RHevening, $0-2555.0 \mathrm{~mm}$ total rainfall, 3.65 $-9.03 \mathrm{hrs}$ sunshine and $0-1.28 \mathrm{~km} / \mathrm{hr}$ wind speed. The Multiple regression equation derived from the data revealed that the percent disease incidence was influenced by maxT (2.81 units), minT (1.78 units), RHmorning (3.49 units), RHevening (1.62 units), rainfall (0.001 units), sunshine hours (9.58 units) and wind speed (18.99 units). It indicated that with increase in RHevening, rainfall and sunshine hours there was significant increase in percent disease incidence whereas with decrease in RHmorning, $\operatorname{maxT}$, minT and wind speed there was increase in disease incidence. It was confirmed by high $\mathrm{R}^{2}$ value $(0.957)$.

The equation was,

$\hat{\mathrm{Y}}=328.83-2.81 \max \mathrm{T}-1.78 \min \mathrm{T}-3.49$ RHmorning +1.62 RHevening +0.00 rainfall +9.58 sunshine -18.99 wind speed

While deriving on step down regression equation of percent disease incidence of Target leaf spot disease of White sarpagandha, it was clearly observed that minT (4.45 units) had negative impact on percent disease incidence, in contrast wind speed (23.43 units) had significant negative impact on percent disease incidence (Table 4).

During second year (July,15 - June,16), the prediction equation for percent disease incidence of leaf spot disease caused by Corynespora cassicola indicated that minT, RHmorning, sunshine hours and wind speed were positively and maxT, RHevening and rainfall were negatively correlated with percent disease incidence. The coefficient of determination $\left(\mathrm{R}^{2}\right)$ between percent disease incidence and seven groups of independent variables was found to be 0.911 suggesting 
that $91.1 \%$ change in percent disease incidence was caused by these seven factors. During this period of disease development,weather variables varied from $25.60-39.25^{\circ} \mathrm{C} \operatorname{maxT}, 11.65-32.45^{\circ} \mathrm{C}$ minT, 88.88 - $98.2 \%$ RHmorning, 46.63 $86.00 \%$ RHevening, $0-2844.80 \mathrm{~mm}$ total rainfall, $2.50-8.35 \mathrm{hrs}$ sunshine and $0.03-$ $1.70 \mathrm{~km} / \mathrm{hr}$ wind speed. The Multiple regression equation derived from the data revealed that the disease incidence influenced by $\operatorname{maxT}$ (10.57 units), minT (3.45 units), RHmorning (27.16 units), RHevening (4.73 units), rainfall (0.01 units), sunshine hours (10.04 units), wind speed (43.48 units). It indicated that with increase in minT, RHmorning, sunshine and wind speed there was significant increase in percent disease incidence whereas with decrease in maxT, RHevening and rainfall there was significant increase in percent disease incidence. It was confirmed by high $\mathrm{R}^{2}$ value $(0.911)$.

The equation was,

$\hat{\mathrm{Y}}=-1999.50-10.57 \operatorname{maxT}+3.45 \operatorname{minT}+$ 27.16 RHmorning - 4.73 RHevening - 0.01 rainfall +10.04 sunshine +43.48 wind speed

While deriving on step down regression equation of percent disease incidence of white sarpagandha it was clearly observed that minT (4.43 units) had negative impact on percent disease incidence (Table 4).

From these two years data pooled data was calculated and from that pooled data, the prediction equation for percent disease incidence of target leaf spot disease caused by Corynespora cassicola indicated that minT and sunshine were positively and RHevening, RHmorning maxT, wind speed and rainfall were negatively correlated with percent disease incidence. The coefficient of determination $\left(\mathrm{R}^{2}\right)$ between percent disease incidence and seven groups of independent variables was found to be 0.830 suggesting that $83.0 \%$ change in disease incidence was caused by these seven factors. Weather variables varied from $26.13-37.52^{\circ} \mathrm{C}$ maxT, $11.63-29.70^{\circ} \mathrm{C} \operatorname{minT}, 86.00-97.13 \%$ RHmorning, 42.88 - 84.75\% RHevening, $0-$ $2252.25 \mathrm{~mm}$ total rainfall, $3.08-8.15 \mathrm{hrs}$ sunshine and $0.01-1.25 \mathrm{~km} / \mathrm{hr}$ wind speed. The Multiple regression equation derived from the data revealed that the percent disease incidence influenced by maxT (5.92 units), minT (0.46 units), RHmorning (0.19 units), RHevening (0.59 units), rainfall (0.004 units), sunshine hours (5.78 units), wind speed (21.34 units). It indicated that with increase in minT and sunshine hrs. There was significant increase in percent disease incidence whereas with decrease in RHevening, RHmorning, maxT, wind speed and rainfall there was increase in percent disease incidence. It was confirmed by high $\mathrm{R}^{2}$ value $(0.830)$.

The equation was,

$\hat{\mathrm{Y}}=226.25-5.92 \max \mathrm{T}+0.46 \min \mathrm{T}-0.19$ RHmorning - 0.59 RHevening -0.00 rainfall +5.78 sunshine -21.34 wind speed

While deriving on step down regression equation of percent disease incidence of white sarpagandha it was clearly observed that minT (4.35 units) had negative impact on percent disease incidence (Figure 1), in contrast wind speed (19.97 units) had negative impact on percent disease incidence (Table 4).

\section{Rust disease of Bach}

In Bach, during first year (July,14 - June,15) (Table 4), the prediction equation for percent disease incidence of leaf spot disease caused by Uromyces acori indicated that sunshine hours and RHevening were positively and wind speed, $\operatorname{maxT}$, minT, rainfall and RHmorning were negatively correlated with percent disease incidence. 
Table.1 Leaf spot diseases and their causal organisms

\begin{tabular}{|c|c|c|c|}
\hline Medicinal plants & Diseases & Causal organisms & Scientist \\
\hline White sarpagandha & Target spot & $\begin{array}{c}\text { Corynespora } \\
\text { cassicola }\end{array}$ & Paul,2013 \\
\hline Bach & Rust & Uromyces acori & $\begin{array}{c}\text { Nirmalkar and } \\
\text { Lakpale, 2008 }\end{array}$ \\
\hline
\end{tabular}

Table.2 Percent Disease incidence of target leaf spot of white sarpagandha and rust disease of bach for two years in kalyani

\begin{tabular}{|c|c|c|r|c|c|r|r|}
\hline \multirow{2}{*}{$\begin{array}{c}\text { Medicinal } \\
\text { plants }\end{array}$} & \multicolumn{5}{|c|}{ White sarpagandha } & \multicolumn{3}{c|}{ Bach } \\
\cline { 2 - 7 } Months & $\begin{array}{c}\text { July,14- } \\
\text { June,15 }\end{array}$ & $\begin{array}{c}\text { July,15- } \\
\text { June,16 }\end{array}$ & Pooled data & $\begin{array}{c}\text { July,14- } \\
\text { June, } 15\end{array}$ & $\begin{array}{c}\text { July, } 15- \\
\text { June, } 16\end{array}$ & Pooled data \\
\hline July & 19.33 & 17.33 & 18.33 & 20.00 & 21.33 & 20.66 \\
\hline August & 23.33 & 27.33 & 25.33 & 21.55 & 22.36 & 21.95 \\
\hline September & 52.67 & 57.33 & 55.00 & 50.33 & 52.66 & 51.49 \\
\hline October & 70.00 & 72.00 & 71.00 & 70.33 & 72.33 & 71.33 \\
\hline November & 81.33 & 85.33 & 83.33 & 82.33 & 82.56 & 82.44 \\
\hline December & 82.23 & 85.57 & 83.90 & 83.66 & 83.67 & 83.66 \\
\hline Janauary & 82.66 & 86.32 & 84.49 & 83.98 & 83.89 & 83.93 \\
\hline February & 82.98 & 86.54 & 84.76 & 84.00 & 84.00 & 84.00 \\
\hline March & 56.98 & 52.50 & 54.74 & 57.33 & 56.66 & 56.99 \\
\hline April & 21.89 & 25.66 & 23.78 & 23.66 & 25.33 & 24.49 \\
\hline May & 7.33 & 11.56 & 9.45 & 15.66 & 16.66 & 16.16 \\
\hline June & 4.00 & 5.33 & 4.67 & 7.33 & 8.00 & 7.66 \\
\hline
\end{tabular}

Table.3 Correlation co-efficients of percent disease incidence of target leaf spot of white sarpagandha and rust disease of bach

\begin{tabular}{|c|c|c|c|c|c|c|c|c|}
\hline Diseases & Year & $\begin{array}{c}\text { Maximum } \\
\text { temparatur } \\
\left.\text { e ( }{ }^{\circ} \mathrm{c}\right)\end{array}$ & $\begin{array}{c}\text { Minimum } \\
\text { temperatur } \\
\mathrm{e}\left({ }^{\circ} \mathrm{c}\right)\end{array}$ & $\begin{array}{c}\text { RH } \\
\text { Mornin } \\
\text { g } \%\end{array}$ & $\begin{array}{c}\text { RH } \\
\text { evening } \\
\%\end{array}$ & $\begin{array}{c}\text { Rainfall } \\
\text { (mm) }\end{array}$ & $\begin{array}{l}\text { Sunshi } \\
\text { ne hrs }\end{array}$ & $\begin{array}{l}\text { Wind } \\
\text { speed }\end{array}$ \\
\hline \multirow{3}{*}{$\begin{array}{c}\text { Target leaf } \\
\text { spot of White } \\
\text { sarpagandha }\end{array}$} & $1 \mathrm{st}$ & $-0.703^{*}$ & $-0.867^{* *}$ & $0.722^{\text {*** }}$ & -0.487 & $-0.663^{*}$ & 0.352 & $-0.700^{*}$ \\
\hline & 2nd & $-0.741^{* *}$ & $-0.816^{* *}$ & -0.106 & -0.526 & $-0.579^{*}$ & -0.25 & -0.545 \\
\hline & $\begin{array}{c}\text { Poole } \\
\text { d }\end{array}$ & $-0.722^{* *}$ & $-0.831^{* *}$ & -0.395 & $-0.504^{*}$ & $-0.622^{* *}$ & 0.02 & $0.604^{* *}$ \\
\hline \multirow{3}{*}{$\begin{array}{c}\text { Rust disease } \\
\text { of Bach }\end{array}$} & $1 \mathrm{st}$ & $-0.703^{*}$ & $-0.883^{* *}$ & $\begin{array}{c}- \\
0.754^{* *}\end{array}$ & -0.522 & $-0.710^{* *}$ & 0.377 & $-0.653^{*}$ \\
\hline & 2nd & $-0.747^{* * *}$ & $-0.821^{* * *}$ & -0.13 & -0.537 & $-0.593^{*}$ & -0.248 & -0.533 \\
\hline & $\begin{array}{c}\text { Poole } \\
\text { d }\end{array}$ & $-0.722^{* *}$ & $-0.845^{* *}$ & $-0.438^{*}$ & $-0.527^{* *}$ & $-0.653^{* *}$ & 0.039 & $\begin{array}{c}- \\
0.581^{* *}\end{array}$ \\
\hline
\end{tabular}




\section{Int.J.Curr.Microbiol.App.Sci (2017) 6(10): 3529-3538}

Table.4 Full and step down prediction equation of percent disease incidence of leaf spot diseases of medicinal plants

\begin{tabular}{|c|c|c|c|c|c|c|}
\hline Medicinal plants & Year & MRA & Prediction equation & $\mathrm{R}^{2}$ & Adj. $R^{2}$ & SE estimate \\
\hline \multirow{8}{*}{$\begin{array}{l}\text { White } \\
\text { sarpagandha }\end{array}$} & \multirow{3}{*}{$1 \mathrm{st}$} & Full & $\begin{array}{l}=328.832-2.815 \mathrm{x}_{1}-1.787 \mathrm{x}_{2}-3.491 \mathrm{x}_{3}+1.628 \mathrm{x}_{4}+0.001 \mathrm{x}_{5}+9.587 \mathrm{x}_{6}- \\
18.991 \mathrm{x}_{7}\end{array}$ & 0.957 & 0.881 & 10.900 \\
\hline & & \multirow{2}{*}{ Step down } & $=142.896-4.456 \mathrm{x}_{2}$ & 0.752 & 0.727 & 16.512 \\
\hline & & & $=129.206-3.544 \mathrm{x}_{2}-23.434 \mathrm{x}_{7}$ & 0.847 & 0.813 & 13.669 \\
\hline & \multirow[t]{2}{*}{ 2nd } & Full & $\begin{array}{l}=-1999.506-10.571 \mathrm{x}_{1}+3.450 \mathrm{x}_{2}+27.169 \mathrm{x}_{3}-4.732 \mathrm{x}_{4}-0.017 \mathrm{x}_{5}+10.041 \mathrm{x}_{6} \\
+43.483 \mathrm{x}_{7}\end{array}$ & 0.911 & 0.756 & 15.871 \\
\hline & & Step down & $=150.813-4.431 \mathrm{x}_{2}$ & 0.666 & 0.633 & 19.462 \\
\hline & \multirow{3}{*}{ Pooled } & Full & $\begin{array}{l}=226.252-5.923 \mathrm{x}_{1}+0.464 \mathrm{x}_{2}-0.194 \mathrm{x}_{3}-0.599 \mathrm{x}_{4}-0.004 \mathrm{x}_{5}+5.788 \mathrm{x}_{6}- \\
21.341 \mathrm{x}_{7}\end{array}$ & 0.830 & 0.755 & 15.435 \\
\hline & & \multirow{2}{*}{ Step down } & $=144.990-4.357 \mathrm{x}_{2}$ & 0.690 & 0.676 & 17.760 \\
\hline & & & $=136.325-3.676 \mathrm{x}_{2}-19.971 \mathrm{x}_{7}$ & 0.776 & 0.755 & 15.449 \\
\hline \multirow{6}{*}{ Antamul } & \multirow[t]{2}{*}{$1 \mathrm{st}$} & Full & $\begin{array}{l}=-135.971+6.554 \mathrm{x}_{1}-7.428 \mathrm{x}_{2^{-}}-0.739 \mathrm{x}_{3}+2.456 \mathrm{x}_{4}-0.008 \mathrm{x}_{5}+2.575 \mathrm{x}_{6}+ \\
1.175 \mathrm{x}_{7}\end{array}$ & 0.930 & 0.808 & 7.906 \\
\hline & & Step down & $=72.039-2.461 \mathrm{x}_{2}$ & 0.704 & 0.674 & 10.298 \\
\hline & \multirow[t]{2}{*}{ 2nd } & Full & $\begin{array}{l}=-1663.092-5.568 x_{1}+0.606 x_{2}+20.882 x_{3}-2.400 x_{4}-0.016 x_{5}+6.662 x_{6}+ \\
45.757 x_{7}\end{array}$ & 0.847 & 0.579 & 11.757 \\
\hline & & Step down & $=76.847-2.468 x_{2}$ & 0.649 & 0.614 & 11.267 \\
\hline & \multirow[t]{2}{*}{ Pooled } & Full & $\begin{array}{l}=68.480-2.147 \mathrm{x}_{1}-0.764 \mathrm{x}_{2}+0.151 \mathrm{x}_{3}+0.346 \mathrm{x}_{4}-0.008 \mathrm{x}_{5}+1.965 \mathrm{x}_{6}- \\
5.763 \mathrm{x}_{7}\end{array}$ & 0.776 & 0.678 & 10.038 \\
\hline & & Step down & $=73.406-2.417 \mathrm{x}_{2}$ & 0.659 & 0.643 & 10.568 \\
\hline
\end{tabular}

$\mathrm{x}_{1}=$ Maximum temperature $\left({ }^{\circ} \mathrm{C}\right)(\operatorname{maxT}), \mathrm{x}_{2}=$ Minimum temperature $\left({ }^{\circ} \mathrm{C}\right)(\operatorname{minT}), \mathrm{x}_{3}=$ Relative humidity at morning $(\%)(\mathrm{RHmorning})$

$\mathrm{x}_{4}=$ Relative humidity at evening (\%) (RHevening), $\mathrm{x}_{5}=$ Rainfall $(\mathrm{mm}), \mathrm{x}_{6}=$ Sunshine (hours), $\mathrm{x}_{7}=$ Wind speed $(\mathrm{km} / \mathrm{hr})$ 


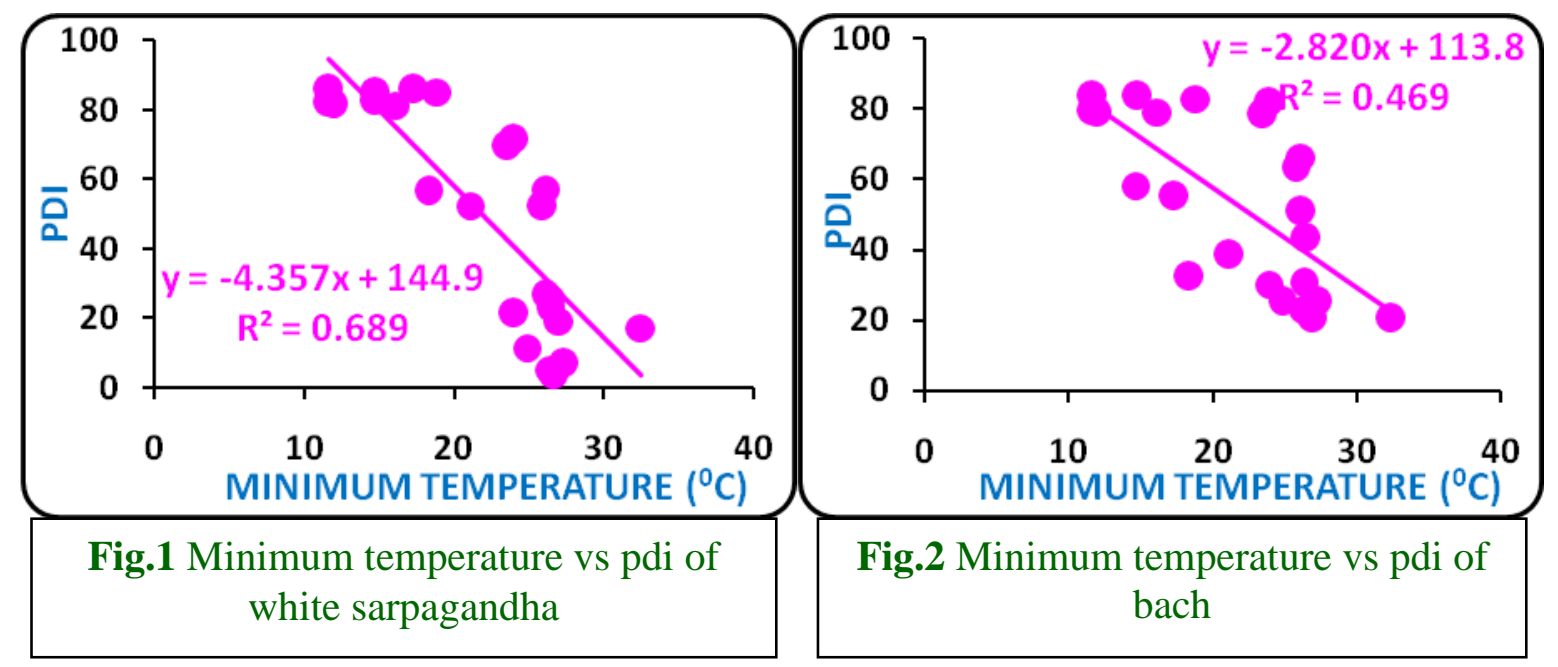

The coefficient of determination $\left(\mathrm{R}^{2}\right)$ between percent disease incidence and seven groups of independent variables was found to be 0.956 suggesting that $95.6 \%$ change in percent disease incidence was caused by these seven factors. During this period of disease development,weather variables varied from $26.53-37.68^{\circ} \mathrm{C} \operatorname{maxT}, 11.60-27.32^{\circ} \mathrm{C}$ $\operatorname{minT}, 80.60$ - 96.00\% RHmorning, $37.25-$ $83.50 \%$ RHevening, $0-2555.0 \mathrm{~mm}$ total rainfall, $3.65-9.03 \mathrm{hrs}$ sunshine and $0-1.28$ $\mathrm{km} / \mathrm{hr}$ wind speed. The Multiple regression equation derived from the data revealed that the percent disease incidence influenced by $\operatorname{maxT}(2.26$ units), $\operatorname{minT}(2.04$ units), RHmorning (3.31 units), RHevening (1.66 units), rainfall (0.002 units), sun shine (8.82 units), wind speed (13.95 units).

It indicated that with increase in sunshine and RHevening there was significant increase in percent disease incidence whereas with decrease in wind speed, maxT, $\operatorname{minT}$, rainfall and RHmorning there was increase in percent disease incidence. It was confirmed by high $\mathrm{R}^{2}$ value (0.956).

The equation was,

$\hat{\mathrm{Y}}=305.86-2.26 \max \mathrm{T}-2.04 \min \mathrm{T}-3.31$ RHmorning + 1.66 RHevening - 0.00 rainfall +8.82 sunshine -13.95 wind speed
While deriving on step down regression equation of percent disease incidence of bach it was clearly observed that minT (4.40 units) had negative significant impact on percent disease incidence (Table 4).

During second year (July,15 - June,16), the prediction equation for percent disease incidence of leaf spot disease caused by Uromyces acori indicated that minT, RHmorning, sunshine and wind speed were positively and maxT, RHevening and rainfall were negatively correlated with percent disease incidence. The coefficient of determination $\left(\mathrm{R}^{2}\right)$ between percent disease incidence and seven groups of independent variables was found to be 0.900 suggesting that $90.0 \%$ change in percent disease incidence was caused by these seven factors. During this period of disease development,weather variables varied from $25.60-39.25^{\circ} \mathrm{C} \operatorname{maxT}, 11.65-32.45^{\circ} \mathrm{C}$ $\operatorname{minT}, 88.88$ - 98.25\% RHmorning, $46.63-$ $86.00 \%$ RHevening, $0-2844.80 \mathrm{~mm}$ total rainfall, $2.50-8.35 \mathrm{hrs}$ sunshine and $0.03-$ $1.70 \mathrm{~km} / \mathrm{hr}$ wind speed. The Multiple regression equation derived from the data revealed that the percent disease incidence influenced by $\operatorname{maxT}$ (8.32 units), $\operatorname{minT}$ (3.68 units), RHmorning (15.73 units), RHevening (3.53 units), rainfall (0.01 units), sunshine hours (5.13 units), wind speed (13.58 units). It 
indicated that with increase in minT, RHmorning, sunshine and wind speed there was significant increase in percent disease incidence whereas with decrease in $\operatorname{maxT}$, RHevening and rainfall there was significant increase in disease incidence. It was confirmed by high $\mathrm{R}^{2}$ value $(0.900)$.

The equation was,

$\hat{\mathrm{Y}}=-1042.12-8.32 \max \mathrm{T}+3.68 \operatorname{minT}+$ 15.73 RHmorning - 3.53 RHevening - 0.01 rainfall +5.13 sunshine +13.58 wind speed

While deriving on step down regression equation of percent disease incidence of bach it was clearly observed that minT (4.20 units) had negative impact on percent disease incidence (Table 4).

From these two years data pooled data was calculated and from that pooled data, the prediction equation for percent disease incidence of leaf spot disease caused by Uromyces acori indicated that $\min \mathrm{T}$ and sunshine hrs were positively and $\operatorname{maxT}$, rainfall, RHmorning RHevening and wind speed were negatively correlated with percent disease incidence. The coefficient of determination $\left(\mathrm{R}^{2}\right)$ between disease incidence and seven groups of independent variables was found to be 0.843 suggesting that $84.3 \%$ change in percent disease incidence was caused by these seven factors. Weather variables varied from $26.13-37.52^{\circ} \mathrm{C}$ maxT, $11.63-29.70^{\circ} \mathrm{C} \operatorname{minT}, 86.00-97.13 \%$ RHmorning, 42.88 - 84.75\% RHevening, 0 $2252.25 \mathrm{~mm}$ total rainfall, $3.08-8.15 \mathrm{hrs}$ sunshine and $0.01-1.25 \mathrm{~km} / \mathrm{hr}$ wind speed. The Multiple regression equation derived from the data revealed that the percent disease incidence influenced by $\operatorname{maxT}$ ( 6.59 units), $\operatorname{minT}$ (1.23 units), RHmorning (0.40 units), RHevening (0.56 units), sunshine hours (5.52 units), wind speed (18.61 units). It indicated that with increase in minT and sunshine hours there was significant increase in percent disease incidence whereas with decrease in maxT, rainfall, RHmorning RHevening and wind speed there was significant increase in percent disease incidence. It was confirmed by high $\mathrm{R}^{2}$ value $(0.843)$.

The equation was,

$\hat{\mathrm{Y}}=285.80-6.59 \max \mathrm{T}+1.23 \min \mathrm{T}-0.40$

RHmorning - 0.56 RHevening - 0.00 rainfall +5.52 sunshine -18.61 wind speed

While deriving on step down regression equation of percent disease incidence of Bach it was clearly observed that minT (4.24 units) had negative impact on percent disease incidence (Figure 2), in contrast wind speed (17.00 units) had significant negative impact on percent disease incidence (Table 4).

The results obtained are in consonance with the observations of Gonavath et.al. (2016) who conducted a field experiment to study the influence of weather parameters on the severity of Corynespora leaf spot of blackgram (Corynespora cassiicola) during 2012-13 at Regional Agricultural Research Station, Lam, Guntur, Andhra Pradesh. The result showed that among the weather parameters studied, maximum temperature (0.31), minimum temperature $(0.70)$, relative humidity at 2.22 P.M (0.50) and rainfall $(0.27)$ were significant and negatively correlating factors with PDI. While, there is a significant positive correlation between PDI and relative humidity at 7.22 A.M (0.36) and sun shine hours (0.42). Paul (2013) stated that percent disease incidence of target leaf spot disease of White Sarpagandha caused by Corynespora cassicola in Kalyani, was negatively correlated with rainfall, maximum and minimum temperature, minimum relative humidity at $1 \%$ level of significance (Table 2).

From the results it can be concluded that in case of target leaf spot of white sarpagandha 
caused by Corynespra cassicola, PDI is increasing with increase in minimum temperature and sunshine hours and with decrease in $\mathrm{RH}$ evening, $\mathrm{RH}$ morning, maximum temperature, wind speed and rainfall. In case of rust disease of Bach caused by Uromyces acori, PDI increases with increase in minimum temperature and sunshine hours and with decrease in maximum temperature, rainfall, RH morning, $\mathrm{RH}$ evening and wind speed. The results needs further verification before being forecasting the appearance of the diseases to the medicinal plants growers.

\section{References}

Gonavath, N.S., Adinarayana M., Kumar M.V. and Madhumathi T. 2016. Effect of Weather Parameters on Corynespora
Leaf Spot Disease Severity of Blackgram. IOSR Journal of Agriculture and Veterinary Science (IOSR-JAVS), Volume 9, Issue 2 Ver. II, PP 08-14.

Momin, Ch.E., 2009. Studies on Important Diseases of Medicinal Plants. M.Sc. (Ag.) Dissertation, BCKV, Mohanpur, pp.31-35.

Nirmalkar, V.K., and Lakpale, N. 2008. Symptomatology, characterization and morphological variation of Uromyces acori: a destructive pathogen of sweet flag (Acorus calamus L.). Journal of Soils and Crops, 18(1): 59-61.

Paul, P.C., 2013. Studies on Management of Important Diseases of Some Medicinal Plants. Ph.D (Ag.) Dissertation, BCKV, Mohanpur.

\section{How to cite this article:}

Solanki Sarkar and Basudeb Dasgupta. 2017. Epidemiological Studies of Target Leaf Spot Disease of White Sarpagandha (Rauvolfia serpentine) Caused by Corynespora cassicola and Rust Disease of Bach (Acorus calamus) Caused by Uromyces acori. Int.J.Curr.Microbiol.App.Sci. 6(10): 3529-3538. doi: https://doi.org/10.20546/ijcmas.2017.610.416 